\title{
The knowledge, attitude and behavior levels of midwifery students for the non-pharmacological methods used in the management of labor pain
}

\author{
Ayfer Arslan' ${ }^{1}$ (D), Gamze Temiz² (D) \\ ${ }^{\prime}$ Koç University Hospital, İstanbul, Turkey \\ ${ }^{2}$ Hamidiye Midwifery Faculty, University of Health Sciences, Istanbul, Turkey
}

\begin{abstract}
Objective: We planned and conducted this study to determine the knowledge levels of midwifery students for the non-pharmacological methods used in the management of labor pain and to raise awareness on this topic.

Methods: This descriptive study was conducted with 60 students who attend the Department of Midwifery, Health College, İstanbul Bilim University and accepted to participate in the research. The data were collected by the questionnaire forms upon obtaining the approvals of the institution and the ethics committee. The questionnaires were assessed by SPSS version 22 (SPSS Inc., Chicago, IL, USA).

Results: We found that $43.3 \%(n=26)$ of the midwifery students have knowledge on the non-pharmacological methods and apply at least one of these methods to the pregnant women. When the students were compared according to their grades, it was found that the total scores of responses given by students in 2 nd grade for the questions to determine their attitudes for the non-pharmacological methods used in the management of labor pain were higher in a statistically significant way than the scores of students in 4th grade, and when they were compared in terms of their ages, it was seen that the total scores of the responses given by the students who are 1-19, 22-23 and 24 years old and above for the questions to determine their behaviors were higher in a statistically significant way than the students who are 20-21 years old.

Conclusion: It is needed to increase the knowledge level of the students on the non-pharmacological methods used in the management of labor pain. In order to do this, the knowledge level of the students should be reinforced by using visual learning techniques and simulation practice methods in addition to their theoretical education.
\end{abstract}

Keywords: Midwifery student, pregnant woman, delivery, labor pain, non-pharmacological.
Özet: Ebelik öğrencilerinin doğum ağrısının yönetiminde kullanılan nonfarmakolojik yöntemlere ilişkin bilgi, tutum ve davranışları

Amaç: Bu çalışma ebelik öğrencilerinin doğum ağrısının yönetiminde kullanılan nonfarmakolojik yöntemler konusundaki bilgi düzeylerinin belirlenmesi ve farkındalıklarının arttırılması amacıyla planlandı ve uygulandi.

Yöntem: Araştırma İstanbul Bilim Üniversitesi Sağlık Yüksekokulu Ebelik bölümünde okuyan ve araştırmaya katılmayı kabul eden 60 öğrenci ile tanımlayıcı olarak yürütüldü. Veriler kurum izni ve etik kurul onayı alınarak anket formu ile toplandı. Anketler SPSS versiyon 22 (SPSS Inc., Chicago, IL, ABD) program kullanılarak değerlendirildi.

Bulgular: Araştırmaya göre ebelik öğrencilerinin \%43.3'ünün $(n=26)$ nonfarmakolojik yöntemler hakkında bilgi sahibi olduğu ve bu yöntemlerden en az bir tanesini gebeye uyguladığı saptandı. Öğrenim gördükleri sınıfa göre karşılaştırıldığında; 2. sınıfların doğum ağrısının yönetiminde kullanılan nonfarmakolojik yöntemlere ilişkin tutumlarını belirlemeye yönelik sorulara verdikleri cevapların toplam puanlarının, 4. sınıfların puanlarına göre istatistiksel olarak anlamlı derecede yüksek olduğu; yaşları karşılaştırıldığında ise $18-19,22-23$ ve 24 yaş ve üzeri öğrenci ebelerin davranışlarını belirlemeye yönelik sorulara verdikleri cevapların toplam puanlarının, 20-21 yaş grubundaki öğrenci ebelerin puanlarına göre istatistiksel olarak anlamlı derecede yüksek olduğu bulundu.

Sonuç: Öğrencilerin doğum ağrısının yönetiminde kullanılan nonfarmakolojik yöntemler konusunda bilgilerinin artırılmasına gereksinim vardır. Bunun için konu ile ilgili teorik eğitimlerin yanı sıra, görsel öğrenme teknikleri ve simülasyon uygulama yöntemleri de kullanılarak öğrencilerin bilgileri pekiştirilmelidir.

Anahtar sözcükler: Öğrenci ebe, gebe, doğum, doğum ağrısı, nonfarmakolojik.

Correspondence: Ayfer Arslan. Koç University Hospital, İstanbul, Turkey.

e-mail: arslan-ayfer@hotmail.com / Received: August 2, 2019; Accepted: September 20, 2019

Please cite this article as: Arslan A, Temiz G. The knowledge, attitude and behavior levels of midwifery students for the non-pharmacological methods used in the management of labor pain. Perinatal Journal 2019;27(2):77-88. doi:10.2399/prn.19.0272006 


\section{Introduction}

The labor is a clinical process starting with the cervical dilation and resulting in the expulsion of placenta and its members, and it is one of the reasons for the most intense pain types known and defined so far. ${ }^{[1-3]}$ The pain developed by labor's nature affects the perception of pregnant women towards labor. Uncontrolled pain may cause pregnant women to perceive labor negatively, to have negative experiences about and dissatisfy with the labor, and may lead to postpartum depression, posttraumatic stress disorder, sexual dysfunction, insufficient attachment between mother and newborn, breastfeeding issues and situations such as mother neglecting newborn. ${ }^{[-8]}$

Labor pain is a part of the natural process. While other pain types indicate a disease or disorder, labor pain is the sign of a good outcome expected. Each labor pain has certainly a preparation period and a particular time span. It does not last for days or months. It is not continuous, but intermittent. As the labor progresses, the intensity and duration of the pain increase. .1,2,5, 10] $^{-1}$

Labor pain is affected by many factors such as the duration of delivery, the duration and dosage of epidural analgesia, use of oxytocin or misoprostol, amniotomy, size and position of fetus, maternal psychology, delivery position, number of delivery and pelvic anatomy. ${ }^{[3,5,6,11,12]}$

The failure of pain control eliminated the ideas that labor pain is acceptable or necessary, and the presence of pain was considered to be an indication for treatment. Although many studies have been conducted and many different methods have been tried, it has been found out that labor pain still cannot be managed by pregnant women. The pain felt causes stress response and this maternal change affects fetus negatively. Fear, stress and pain may prolong labor duration by decreasing uterine activity. This has led both pregnant women and caretakers to seek different approaches for pain management. ${ }^{[2,4,6,8,13,14]}$

Relieving the labor pain has become a mystery for researchers for many years, and therefore many pharmacological and non-pharmacological methods have been developed. The purpose of the methods used to relieve labor pain is to reduce or regulate labor pain directly without causing any effect on mother and fetus. Pharmacological methods are based on the use of various analgesic and anesthetic substances via different methods. In recent years, non-pharmacological methods have been developed alternatively due to the fact that pharmacological methods are expensive and have potential side effects. These methods are preferred as they are ease to use and have less side effects as well as being economic. Also, the pregnant women who use the method express higher level of satisfaction as they feel that they have the control. ${ }^{[1-7,9,11]}$

The non-pharmacological methods used in pain control include various techniques not only reduce the physical effects of the pain but also to reinforce the psychoemotional and spiritual condition of pregnant women. The most common methods are massage, therapeutic touch, applying pressure on sacrum, superficial heat and cold application, hydrotherapy, effleurage, focus, distraction, feedback relaxation, respiration techniques, hypnosis, music, aquatic therapy/water birth, transcutaneous electrical nerve stimulation (TENS), imagination, yoga, biofeedback, aromatherapy, phytotherapy, antenatal training, acupressure (Shiatsu), acupuncture, sophrology (the relaxation technique based on yoga), and movement and position changes. These non-pharmacological methods used to relieve labor pain are the part of midwifery/nursing applications and can be used in labor safely. Therefore, healthcare professionals should guide for the use of these methods in order to reduce the perceived labor pain, help labor to progress and increase the self-confidence of mother. ${ }^{[1-16]}$

The management of labor pain will contribute to the problem-free completion of the labor, immediate start of mother-newborn relationship and the happiness of mother for the process. Informing healthcare professionals about this matter beginning from their school lives will make these methods to be used more actively. For the control of the labor pain and using non-pharmacological methods more during labor, detailed studies are needed.

We believe that the results of this research will provide significant contribution to the evaluation of knowledge, attitude and behavior levels of the midwifery students for the non-pharmacological methods used in the management of labor pain and for raising their awareness.

Following questions were the questions of this research:

- What are the knowledge levels of midwifery students for the non-pharmacological methods used in the management of labor pain? 
- What are the attitude and behavior levels of midwifery students for the non-pharmacological methods used in the management of labor pain?

- Is there a difference between the grades that the students attend and the knowledge, attitude and behavior levels for the non-pharmacological methods used in the management of labor pain?

\section{Methods}

The study is a descriptive research, and it was conducted to determine the knowledge, attitudes and behaviors of students, who attend to the midwifery department of health sciences faculty of a foundation university in İstanbul, for the non-pharmacological methods used in the management of labor pain.

The population of the research consisted of the students attending 1st, 2nd, 3rd and 4th grades of midwifery department. The sample was consisted of midwifery students who were attending $2 \mathrm{nd}$, $3 \mathrm{rd}$ and 4 th grades and meeting the sampling criteria. Attendance to $2 \mathrm{nd}$, 3rd and 4th grades of midwifery department, completing the class of basic principles and applications, having the experience of clinical practice, and willing to participate in the research were the inclusion criteria for the research sampling. In this regard, 60 midwifery students, 25 of whom were in 2 nd grade, 16 of them in 3 rd grade and 19 of them in 4th grade between 15.11.2017 and 30.11.2017 were the sample of the study.

Before the research, the approval of the Ethics Committee of Health Sciences Institute, İstanbul Bilim University was obtained. Institutional approval was obtained for the application. The informed consents of the volunteer students were obtained by informing them about the purpose of the study, and explaining that the results of the evaluation would be kept anonymous and that they can withdraw their consents at any time.

The data were collected by face-to-face interview by the interviewer between 15.11.2017 and 30.11.2017. Each interview took about 15-20 minutes. The data were obtained by "The Student Information Form and The Evaluation Form for Non-pharmacological Methods Used in the Management of Labor Pain”.

\section{Data collection tools}

- Student Information Form: This form includes questions to determine socio-demographic characteristics, employment status and knowledge level of students for the non-pharmacological methods used in the management of labor pain (Table 1).

- Evaluation Form for Non-pharmacological Methods Used in the Management of Labor Pain: This form was prepared by the researches by utilizing the relevant sources. This form includes questions to determine attitudes and behaviors. The form consists of two parts, which are Part A answered as "Yes" or "No", and Part B answered as "True" or "False".

In the questionnaire, each correct answer was awarded 1 point and each wrong answer was awarded 0 point. In the questionnaire, the answer "Yes" for the statements 5, 8, 9, 10,12,13,14, 15, 17, 18, and 19 and the answer "No" for the statements 6, 7, 11, and 16 of the Part A, and the answer "Correct" for the statements $1,4,5,6,7,8,9,10,11,12,13,14$, and 16 and the answer "False" for the statements 3, 15, and 17 of the Part B were considered correct (Table $\mathbf{1}$ ).

The minimum score is 0 and the maximum score is 31 in the Evaluation Form for Non-pharmacological Methods Used in the Management of Labor Pain. The increase in the questionnaire score was interpreted as the increased knowledge level.

\section{Statistical analysis}

The data obtained were analyzed by using SPSS 22 (Statistical Program for Social Sciences; IBM, Chicago, IL, USA). The data were analyzed by using statistical tests such as frequency distribution, arithmetic mean, standard deviation, Kruskal-Wallis test, and Mann-Whitney $\mathrm{U}$ test.

\section{Results}

Of the students, $18.3 \%$ were in the age group of $18-19$, $35 \%$ in $20-21,30 \%$ in $22-23$ and $16.7 \%$ in 24 and above while $41.7 \%$ were in 2 nd grade, $26.7 \%$ in 3 rd grade and $31.7 \%$ in 4 th grade. While $83.3 \%$ of the group has a nuclear family, only $5 \%$ of them are working and $98.3 \%$ of them are having paid education. Also, $96.7 \%$ of the students were graduated from regular high school and $3.3 \%$ of them were graduated from vocational high school of health (Table 2). 
Table 1. The questionnaire form to evaluate the knowledge level of midwifery students on the non-pharmacological methods used in the management of labor pain.

\section{Student Information Form}

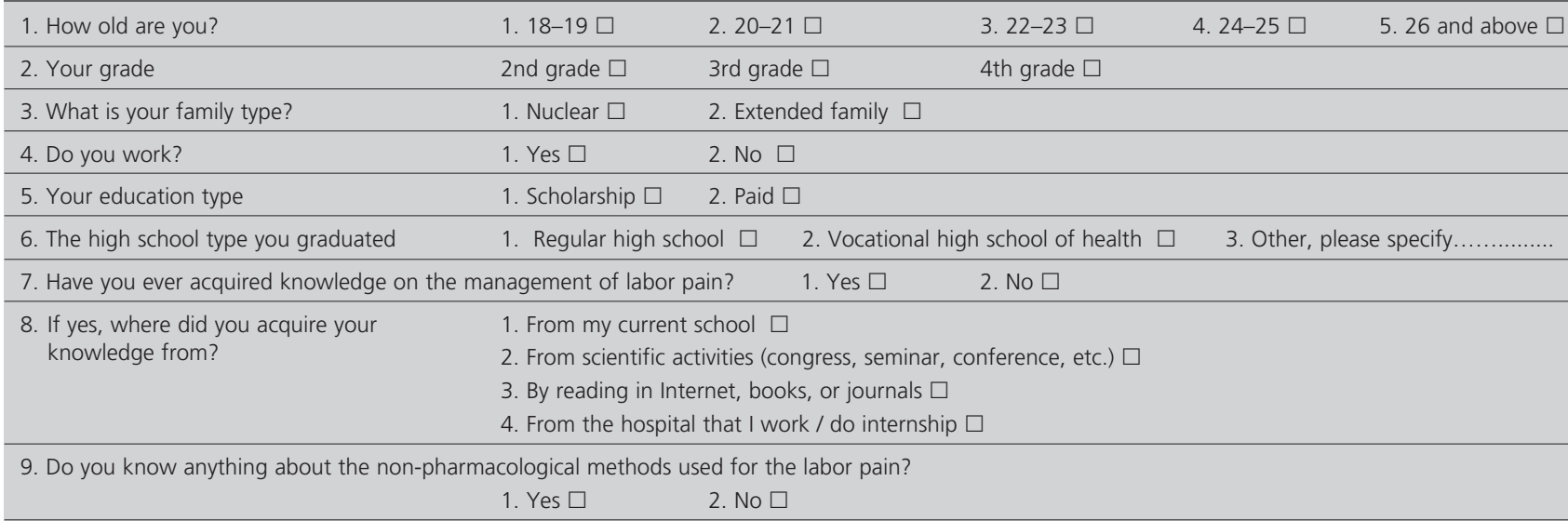

10. If yes, where did you acquire your knowledge from? (You may select multiple options)

1. From the school that I graduated $\square$

2. From my current school $\square$

3. From scientific activities (congress, seminar, conference, etc.) $\square$

4. From the hospital that I work / do internship $\square$

5. From a physician $\square$

6. From a midwife $\square$

7. From a nurse $\square$

8. From books/journals $\square$

9. From scientific publications $\square$

10. From Internet/social networks $\square$

11. Which of the following methods do you know? (You may select multiple options)

1. Massage $\square$

2. Therapeutic touch $\square$

3. Applying pressure on sacrum $\square$

4. Superficial heat and cold application $\square$

5. Hydrotherapy $\square$

6. Focus $\square$

7. Distraction $\square$

8. Feedback relaxation $\square$

9. Respiration techniques $\square$

10. Hypnosis $\square$

11. Music $\square$

12. Aquatic therapy / water birth $\square$

12. Have you ever applied these methods to a pregnant woman?

13. If "Yes", which of the methods did you apply? (You may select multiple options)

1. Massage $\square$

2. Therapeutic touch $\square$

3. Applying pressure on sacrum $\square$

4. Superficial heat and cold application $\square$

5. Hydrotherapy $\square$

6. Focus $\square$

7. Distraction $\square$

8. Feedback relaxation $\square$

9. Respiration techniques $\square$

10. Hypnosis $\square$
13. Transcutaneous electrical nerve stimulation (TENS) $\square$

14. Imagination $\square$

15. Yoga $\square$

16. Biofeedback $\square$

17. Aromatherapy $\square$

18. Phytotherapy $\square$

19. Antenatal training $\square$

20. Acupressure (Shiatsu) $\square$

21. Acupuncture $\square$

22. Sophrology (the relaxation technique based on yoga) $\square$

23. Movement and position changes $\square$

Yes $\square$

No $\square$
11. Music $\square$
12. Aquatic therapy / water birth $\square$
13. Transcutaneous electrical nerve stimulation (TENS) $\square$
14. Imagination $\square$
15. Yoga $\square$
16. Biofeedback $\square$
17. Aromatherapy $\square$
18. Phytotherapy $\square$
19. Antenatal training $\square$
20. Movement and position changes 
Table 1. [Continuation] The questionnaire form to evaluate the knowledge level of midwifery students on the non-pharmacological methods used in the management of labor pain.

Evaluation Form for the Knowledge Level on Non-pharmacological Methods Used in the Management of Labor Pain

A- Please read the following statements carefully. Please select either "Yes" or "No" for each statement.

1. I had education about the physiology of labor pain.

2. I have knowledge of pain theories about the management of labor pain.

3. I have knowledge of evaluating labor pain.

4. I had education about the impact of labor pain on labor.

5. Controlling the labor pain is important in the management of labor pain.

6. The methods used are not effective on labor pain. Therefore, it is not necessary to use a non-pharmacological method.

7. Any uneducated person can apply non-pharmacological methods used to relieve labor pain.

8. Any educated person can apply non-pharmacological methods used to relieve labor pain.

9. There are non-pharmacological methods with similar or different application technique.

10. Different methods may be applied according the needs of each pregnant woman.

11. In case of a labor pain, a single method is started and ended. No other method is needed.

12. Non-pharmacological methods used for labor pain help pregnant woman to relax.

13. Providing training to pregnant women for non-pharmacological methods helps their participation in labor positively.

$\begin{array}{cc}\text { Yes } & \text { No } \\ \square & \square\end{array}$

14. Biofeedback, movement/position change, hypnosis, acupuncture, acupressure, music, sophrology, haptonomy and making noise are among the relaxation methods.

15. Appropriate non-pharmacological methods according to the phases of the labor should be applied upon the consent of pregnant woman.

16. It is not necessary to record the method used for labor pain.

17. The respiratory techniques are applied through 4 levels of respiration.

$\square \quad \square$

$\square$

$\square \quad \square$

$\square \quad \square$

18. Applying non-pharmacological methods increases the confidence of pregnant woman towards healthcare professional.

$\square \quad \square$

$\square \quad \square$

19. Physical application methods are performed by TENS, intradermal fluid injection, superficial heat-cold application, hydrotherapy/bath/shower, massage and aromatherapy.

B- Please read the following statements carefully. Indicate your attitude about the methods by writing (T) if it is true or (F) if it is false on the blank part before each statement.

$\square \quad$ 1. This is a team work. Education is required before practice.

$\square \quad$ 2. I am not interested on this subject, I do not want to do anything.

$\square$ 3. If I have the opportunity, I initiate the application on my own.

$\square \quad 4$. I consult to my trainer for the methods.

$\square \quad 5.1$ choose the method according to the pregnant woman by considering the setting

$\square \quad 6$. I can use many methods together.

$\square \quad$ 7. I inform the pregnant woman and her family in advance about the non-pharmacological method

$\square$ 8. When I fail about the method, I try to improve my weaknesses with the help of my trainer.

$\square \quad 9.1$ investigate if the method used is effective or not by using a pain scale.

$\square \quad$ 10. I continue to use the method when I see the effects of the method used.

$\square \quad$ 11. I involve the family of pregnant woman into the process while applying the methods.

$\square$ 12. It is useful to increase the number of training classes for the application of these methods

$\square$ 13. It should be taught in school how these methods are applied.

$\square$ 14. The physical setting to apply methods should be arranged in delivery rooms

$\square \quad$ 15. I believe that I do not have sufficient knowledge to apply the method.

$\square \quad$ 16. I record every application performed, and share the results with other team members.

$\square$ 17. These applications are not practiced in delivery rooms, I do not find it necessary. 
Table 2. The distribution of the students according to their sociodemographic characteristics $(n=60)$.

\begin{tabular}{llcc} 
Characteristics & Category & $\mathbf{n}$ & $\%$ \\
\hline Age & $18-19$ & 11 & 18.3 \\
& $20-21$ & 21 & 35.0 \\
& $22-23$ & 18 & 30.0 \\
& 24 and above & 10 & 16.7 \\
\hline \multirow{2}{*}{ Grade } & 2nd grade & 25 & 41.7 \\
& 3rd grade & 16 & 26.7 \\
& 4th grade & 19 & 31.7 \\
\hline Family type & Nuclear family & 50 & 83.3 \\
& Extended family & 10 & 16.7 \\
\hline Employment & Yes & 3 & 5.0 \\
status & No & 57 & 95.0 \\
\hline Education type & Scholarship & 1 & 1.7 \\
& Paid & 59 & 98.3 \\
\hline The high school & Regular high school & 58 & 96.7 \\
type graduated & Vocational high school of health & 2 & 3.3 \\
\hline
\end{tabular}

Of the midwifery students, $63.3 \%$ had knowledge of the management of labor pain. Accordingly, it was found that $56.7 \%$ of the students acquired their knowledge on the management of labor pain from their current school, $3.3 \%$ of them from Internet, $3.3 \%$ of them from the hospital they work, and $70 \%$ of them had knowledge of the non-pharmacological methods used in the management of the labor pain, and $63.3 \%$ of them acquired their knowledge on the non-pharmacological methods used in the management of the labor pain from their current school, $1.7 \%$ of them from scientific activities such as congresses or seminars, $41.7 \%$ of them from the hospital, $1.7 \%$ of them from a physician, $43.3 \%$ of them from a midwife, $13.3 \%$ of them from a nurse, $5 \%$ of them from books and journals, 35\% of them from scientific publications, and $41.7 \%$ of them from Internet and social networks.

When the midwifery students were asked the nonpharmacological methods used for labor pain, the group stated that massage, movement and position change and therapeutic palpation were the methods they know the most, and aromatherapy, sophrology, acupressure and phytotherapy were the methods they know the least, respectively. It was found that $43.3 \%$ of the students applied these methods to a pregnant woman previously. Accordingly, it was found that the most common methods used by the students were movement and position changes, massage and focus, respectively (Table 3).
When the answers of midwifery students given for the Attitude scale of the knowledge evaluation form for the non-pharmacological methods used in the management of labor pain were analyzed, it was found that they gave correct answer for the statement "Applying nonpharmacological methods increases the confidence of pregnant woman towards healthcare professional". This statement was followed by the statements "Appropriate non-pharmacological methods according to the phases of the labor should be applied upon the consent of pregnant woman" and "Non-pharmacological methods used for labor pain help pregnant woman to relax". On the other hand, the statement that was given wrong answer the most was "It is not necessary to record the method used for labor pain". The other statements that were given wrong answer the most were "I had education about the physiology of labor pain" and "I have knowledge of pain theories about the management of labor pain" (Table 4).

When the answers of midwifery students participated in the research given for the Behavior scale of the knowledge evaluation form for the non-pharmacological methods used in the management of labor pain were analyzed, it was seen that the students gave correct answer for the statements "This is a team work. Education is required before practice", "I inform the pregnant woman and her family in advance about the non-pharmacological method" and "These applications are not practiced in delivery rooms, I do not find it necessary". On the other hand, the statement that was given wrong answer the most was "I record every application performed, and share the results with other team members" which was followed by the statements "If I have the opportunity, I initiate the application on my own", and "I believe that I do not have sufficient knowledge to apply the method" (Table 5).

It was seen that the Attitude sub-scale scores of the midwifery students in the knowledge evaluation form for the non-pharmacological methods used in the management of labor pain ranged from 10 to 19 , and the mean score was $13.35 \pm 1.999$, the Behavior sub-scale scores ranged from 0 to 17 , and the mean score was $13.00 \pm 1.426$ (Table 6)

The significant socio-demographic characteristics and the characteristics regarding the management of labor pain of the midwifery students who participated in this research were compared to their scores in the knowledge evaluation form for the non-pharmacological methods used in the management of labor pain. 
Table 3. The distribution of midwifery students according to their characteristics regarding to the management of labor pain ( $n=60$ ).

\begin{tabular}{|c|c|c|c|}
\hline Characteristics & Category & $\mathbf{n}$ & $\%$ \\
\hline $\begin{array}{l}\text { Acquiring knowledge on the management of } \\
\text { labor pain previously }\end{array}$ & $\begin{array}{l}\text { Yes } \\
\text { No }\end{array}$ & $\begin{array}{l}38 \\
22\end{array}$ & $\begin{array}{l}63.3 \\
36.7\end{array}$ \\
\hline $\begin{array}{l}\text { The source for acquiring knowledge } \\
\text { on the management of labor pain }\end{array}$ & $\begin{array}{l}\text { From my current school } \\
\text { From Internet } \\
\text { From the hospital I work }\end{array}$ & $\begin{array}{l}34 \\
2 \\
2\end{array}$ & $\begin{array}{l}56.7 \\
3.3 \\
3.3\end{array}$ \\
\hline $\begin{array}{l}\text { Having knowledge of the non-pharmacological } \\
\text { methods used for labor pain }\end{array}$ & $\begin{array}{l}\text { Yes } \\
\text { No }\end{array}$ & $\begin{array}{l}42 \\
18\end{array}$ & $\begin{array}{l}70.0 \\
30.0\end{array}$ \\
\hline $\begin{array}{l}\text { The source where the knowledge of the } \\
\text { non-pharmacological methods used for } \\
\text { labor pain is acquired }\end{array}$ & $\begin{array}{l}\text { From the school that I graduated } \\
\text { From my current school } \\
\text { Scientific activities (congress, etc.) } \\
\text { From the hospital that I work / do internship } \\
\text { From a physician } \\
\text { From a midwife } \\
\text { From a nurse } \\
\text { From books/journals } \\
\text { From scientific publications } \\
\text { From Internet/social networks }\end{array}$ & $\begin{array}{c}2 \\
38 \\
1 \\
25 \\
1 \\
26 \\
8 \\
3 \\
21 \\
25\end{array}$ & $\begin{array}{c}3.3 \\
63.3 \\
1.7 \\
41.7 \\
1.7 \\
43.3 \\
13.3 \\
5.0 \\
35.0 \\
41.7\end{array}$ \\
\hline The methods known & $\begin{array}{l}\text { Massage } \\
\text { Therapeutic touch } \\
\text { Applying pressure on sacrum } \\
\text { Superficial heat and cold application } \\
\text { Hydrotherapy } \\
\text { Focus } \\
\text { Distraction } \\
\text { Feedback relaxation } \\
\text { Respiration techniques } \\
\text { Hypnosis } \\
\text { Music } \\
\text { Aquatic therapy/water birth } \\
\text { Transcutaneous electrical nerve stimulation } \\
\text { Imagination } \\
\text { Yoga } \\
\text { Biofeedback } \\
\text { Aromatherapy } \\
\text { Phytotherapy } \\
\text { Antenatal training } \\
\text { Acupressure } \\
\text { Acupuncture } \\
\text { Sophrology } \\
\text { Movement and position changes }\end{array}$ & $\begin{array}{c}47 \\
33 \\
32 \\
32 \\
10 \\
28 \\
27 \\
15 \\
28 \\
7 \\
32 \\
7 \\
3 \\
15 \\
6 \\
3 \\
3 \\
1 \\
2 \\
31 \\
2 \\
6 \\
2 \\
43\end{array}$ & $\begin{array}{l}78.3 \\
55.0 \\
53.3 \\
53.3 \\
16.7 \\
46.7 \\
45.0 \\
25.0 \\
46.7 \\
11.7 \\
53.3 \\
11.7 \\
5.0 \\
25.0 \\
10.0 \\
5.0 \\
1.7 \\
3.3 \\
51.7 \\
3.3 \\
10.0 \\
3.3 \\
71.7\end{array}$ \\
\hline Application of known methods to a pregnant woman & $\begin{array}{l}\text { Yes } \\
\text { No }\end{array}$ & $\begin{array}{l}26 \\
33\end{array}$ & $\begin{array}{l}43.3 \\
55.0\end{array}$ \\
\hline The method applied & $\begin{array}{l}\text { Massage } \\
\text { Therapeutic touch } \\
\text { Applying pressure on sacrum } \\
\text { Superficial heat and cold application } \\
\text { Hydrotherapy } \\
\text { Focus } \\
\text { Distraction } \\
\text { Feedback relaxation } \\
\text { Respiration techniques } \\
\text { Hypnosis } \\
\text { Music } \\
\text { Aquatic therapy/water birth } \\
\text { Transcutaneous electrical nerve stimulation } \\
\text { Imagination } \\
\text { Yoga } \\
\text { Biofeedback } \\
\text { Aromatherapy } \\
\text { Phytotherapy } \\
\text { Antenatal training } \\
\text { Movement and position changes }\end{array}$ & $\begin{array}{c}24 \\
18 \\
19 \\
15 \\
0 \\
20 \\
17 \\
5 \\
8 \\
0 \\
19 \\
0 \\
0 \\
9 \\
0 \\
0 \\
0 \\
0 \\
1 \\
25\end{array}$ & $\begin{array}{r}40.0 \\
30.0 \\
31.7 \\
25.0 \\
- \\
33.3 \\
28.3 \\
8.3 \\
13.3 \\
- \\
31.7 \\
- \\
- \\
15.0 \\
- \\
- \\
- \\
- \\
1.7 \\
41.7\end{array}$ \\
\hline
\end{tabular}


Table 4. The distribution of the responses of midwifery students given for the Attitude sub-scale items of the Evaluation Form for the Knowledge Level on Non-pharmacological Methods Used in the Management of Labor Pain ( $n=60)$.

\begin{tabular}{|c|c|c|c|c|}
\hline \multirow[b]{2}{*}{ Attitude sub-scale items } & \multicolumn{2}{|c|}{ Yes } & \multicolumn{2}{|c|}{ No } \\
\hline & $\mathbf{n}$ & $\%$ & $\mathbf{n}$ & $\%$ \\
\hline 1. I had education about the physiology of labor pain. & 44 & 73.3 & 16 & 26.7 \\
\hline 2. I have knowledge of pain theories about the management of labor pain. & 44 & 73.3 & 16 & 26.7 \\
\hline 3. I have knowledge of evaluating labor pain. & 42 & 70.0 & 18 & 30.0 \\
\hline 4. I had education about the impact of labor pain on labor. & 41 & 68.3 & 19 & 31.7 \\
\hline 5. Controlling the labor pain is important in the management of labor pain. & 53 & 88.3 & 7 & 11.7 \\
\hline 6. The methods used are not effective on labor pain. Therefore, it is not necessary to use a non-pharmacological method. & 10 & 16.7 & 50 & 83.3 \\
\hline 7. Any uneducated person can apply non-pharmacological methods used to relieve labor pain. & 17 & 28.3 & 43 & 71.7 \\
\hline 8. Any educated person can apply non-pharmacological methods used to relieve labor pain. & 40 & 66.7 & 20 & 33.3 \\
\hline 9. There are non-pharmacological methods with similar or different application technique. & 55 & 91.7 & 5 & 8.3 \\
\hline 10. Different methods may be applied according the needs of each pregnant woman. & 54 & 90.0 & 6 & 10.0 \\
\hline 11. In case of a labor pain, a single method is started and ended. No other method is needed. & 35 & 58.3 & 25 & 41.7 \\
\hline 12. Non-pharmacological methods used for labor pain help pregnant woman to relax. & 58 & 96.7 & 2 & 3.3 \\
\hline 13. Providing training to pregnant women for non-pharmacological methods helps their participation in labor positively. & 56 & 93.3 & 4 & 6.7 \\
\hline $\begin{array}{l}\text { 14. Biofeedback, movement/position change, hypnosis, acupuncture, acupressure, music, sophrology, haptonomy and } \\
\text { making noise are among the relaxation methods. }\end{array}$ & 56 & 93.3 & 4 & 6.7 \\
\hline $\begin{array}{l}\text { 15. Appropriate non-pharmacological methods according to the phases of the labor should be applied upon } \\
\text { the consent of pregnant woman. }\end{array}$ & 59 & 98.3 & 1 & 1.7 \\
\hline 16. It is not necessary to record the method used for labor pain. & 49 & 81.7 & 11 & 18.3 \\
\hline 17. The respiratory techniques are applied through 4 levels of respiration. & 57 & 95.0 & 3 & 5.0 \\
\hline 18. Applying non-pharmacological methods increases the confidence of pregnant woman towards healthcare professional. & 60 & 100 & 0 & - \\
\hline $\begin{array}{l}\text { 19. Physical application methods are performed by TENS, intradermal fluid injection, superficial heat-cold application, } \\
\text { hydrotherapy/bath/shower, massage and aromatherapy. }\end{array}$ & 55 & 91.7 & 5 & 8.3 \\
\hline
\end{tabular}

Table 5. The distribution of the responses of midwifery students given for the Behavior sub-scale items of the Evaluation Form for the Knowledge Level on Non-pharmacological Methods Used in the Management of Labor Pain ( $n=60)$.

\begin{tabular}{|c|c|c|c|c|}
\hline \multirow[b]{2}{*}{ Behavior sub-scale items } & \multicolumn{2}{|c|}{ True } & \multicolumn{2}{|c|}{ False } \\
\hline & $\mathbf{n}$ & $\%$ & n & $\%$ \\
\hline 1. This is a team work. Education is required before practice. & 59 & 98.3 & 1 & 1.7 \\
\hline 2. I am not interested on this subject, I do not want to do anything. & 10 & 16.7 & 50 & 83.3 \\
\hline 3. If I have the opportunity, I initiate the application on my own. & 51 & 85.0 & 9 & 15.0 \\
\hline 4. I consult to my trainer for the methods. & 55 & 91.7 & 5 & 8.3 \\
\hline 5. I choose the method according to the pregnant woman by considering the setting. & 52 & 86.7 & 8 & 13.3 \\
\hline 6. I can use many methods together. & 54 & 90.0 & 6 & 10.0 \\
\hline 7. I inform the pregnant woman and her family in advance about the non-pharmacological method. & 59 & 98.3 & 1 & 1.7 \\
\hline 8. When I fail about the method, I try to improve my weaknesses with the help of my trainer. & 57 & 95.0 & 3 & 5.0 \\
\hline 9. I investigate if the method used is effective or not by using a pain scale. & 52 & 86.7 & 8 & 13.3 \\
\hline 10. I continue to use the method when I see the effects of the method used. & 52 & 86.7 & 8 & 13.3 \\
\hline 11. I involve the family of pregnant woman into the process while applying the methods. & 48 & 80.0 & 12 & 20.0 \\
\hline 12. It is useful to increase the number of training classes for the application of these methods. & 52 & 86.7 & 8 & 13.3 \\
\hline 13. It should be taught in school how these methods are applied. & 50 & 83.3 & 10 & 16.7 \\
\hline 14. The physical setting to apply methods should be arranged in delivery rooms. & 56 & 93.3 & 4 & 6.7 \\
\hline 15. I believe that I do not have sufficient knowledge to apply the method. & 49 & 81.7 & 11 & 18.3 \\
\hline 16. I record every application performed, and share the results with other team members. & 55 & 91.7 & 5 & 8.3 \\
\hline 17. These applications are not practiced in delivery rooms, I do not find it necessary. & 1 & 1.7 & 59 & 98.3 \\
\hline
\end{tabular}


Table 6. The distribution of the scores of the Evaluation Form for the Knowledge Level on Non-pharmacological Methods Used in the Management of Labor Pain $(n=60)$.

\begin{tabular}{lccccc} 
Sub-scale & Potential distribution & $\bar{\chi}$ & \pm SS & Min & Max \\
Attitude sub-scale & $0-19$ & 13.35 & 1.999 & 10 & 19 \\
Behavior sub-scale & $0-17$ & 13.00 & 1.426 & 6 & 15 \\
\hline
\end{tabular}

Accordingly, the Behavior sub-scale scores of the midwifery students in the age groups of $18-19,22-23$ and 24 and above $(13.45 \pm 0.688 ; 13.22 \pm 1.263$ and $13.40 \pm 0.699$, respectively) were higher than the students in the age group of $20-21(12.19 \pm 2.015)$, and the difference was statistically significant $(\mathrm{p}<0.05)$ (Table 7).

The Attitude sub-scale scores of the 2 nd grade midwifery students $(14.24 \pm 2.368)$ were higher than the scores of the 4th grade students $(12.47 \pm 1.124)(\mathrm{p}<0.05)$ (Table 8), and the Attitude sub-scale scores of the midwifery students who did not acquire knowledge on the management of labor pain previously (14.36 \pm 2.441) were higher than the students who acquired their knowledge on the management of labor pain previously (12.76 \pm 1.422$)$, and the difference in both comparisons were statistically significant $(\mathrm{p}<0.05)$ (Table 9).

The Attitude sub-scale scores of the midwifery students who do not have knowledge of the non-pharmacological methods used for labor pain $(14.61 \pm 2.279)$ and the Attitude sub-scale scores of the midwifery students who did not apply the methods they know to a pregnant woman $(14.21 \pm 2.103)$ were high which was statistically significant $(\mathrm{p}<0.05)($ Table 10).

Table 7. The comparison of the scores of the Evaluation Form for the Knowledge Level on Non-pharmacological Methods Used in the Management of Labor Pain according to the age groups of the midwifery students $(n=60)$.

\begin{tabular}{|c|c|c|c|c|c|c|}
\hline Sub-scale & Age group & $\mathbf{n}$ & $\bar{x}$ & \pm SS & $\chi^{2} \mathrm{kw}$ & $\mathbf{p}$ \\
\hline \multirow[t]{4}{*}{ Attitude sub-scale } & $18-19$ & 11 & 14.55 & 2.067 & \multirow{4}{*}{5.935} & \multirow{4}{*}{0.115} \\
\hline & $20-21$ & 21 & 13.05 & 2.012 & & \\
\hline & $22-23$ & 18 & 13.06 & 1.955 & & \\
\hline & 24 and above & 10 & 13.20 & 1.751 & & \\
\hline \multirow[t]{4}{*}{ Behavior sub-scale } & $18-19$ & 11 & 13.45 & 0.688 & \multirow{4}{*}{8.803} & \multirow{4}{*}{0.032} \\
\hline & $20-21$ & 21 & 12.19 & 2.015 & & \\
\hline & $22-23$ & 18 & 13.22 & 1.263 & & \\
\hline & 24 and above & 10 & 13.40 & 0.699 & & \\
\hline
\end{tabular}

$\chi^{2} \mathrm{kw}$ : Kruskal-Wallis test.
Table 8. The comparison of the scores of the Evaluation Form for the Knowledge Level on Non-pharmacological Methods Used in the Management of Labor Pain according to the grades of the midwifery students $(n=60)$.

\begin{tabular}{lcccccc} 
Sub-scale & Grade & $\mathbf{n}$ & $\bar{\chi}$ & \pm SS & $\chi^{2} \mathbf{k w}$ & $\mathbf{p}$ \\
\hline Attitude sub-scale & 2nd grade & 25 & 14.24 & 2.368 & & \\
& 3rd grade & 16 & 13.00 & 1.673 & 9.385 & 0.009 \\
& 4th grade & 19 & 12.47 & 1.124 & & \\
\hline Behavior sub-scale & 2nd grade & 25 & 12.68 & 1.952 & & \\
& 3rd grade & 16 & 12.81 & 1.377 & 2.056 & 0.358 \\
& 4th grade & 19 & 13.37 & 0.761 & & \\
\hline
\end{tabular}

$\chi^{2} \mathrm{kw}$ : Kruskal-Wallis test.

Table 9. The comparison of the scores of the Evaluation Form for the Knowledge Level on Non-pharmacological Methods Used in the Management of Labor Pain according to acquiring knowledge on the management of labor pain previously by midwifery students $(n=60)$

\begin{tabular}{|c|c|c|c|c|c|c|}
\hline Sub-scale & $\begin{array}{l}\text { Acquiring } \\
\text { knowledge on } \\
\text { the management } \\
\text { of labor pain } \\
\text { previously }\end{array}$ & n & $\bar{x}$ & \pm SS & Zmwu & $\mathbf{p}$ \\
\hline Attitude sub-scale & $\begin{array}{l}\text { Yes } \\
\text { No }\end{array}$ & $\begin{array}{l}38 \\
22\end{array}$ & $\begin{array}{l}12.76 \\
14.36\end{array}$ & $\begin{array}{l}1.422 \\
2.441\end{array}$ & -2.862 & 0.004 \\
\hline Behavior sub-scale & $\begin{array}{l}\text { Yes } \\
\text { No }\end{array}$ & $\begin{array}{l}38 \\
22\end{array}$ & $\begin{array}{l}13.26 \\
12.36\end{array}$ & $\begin{array}{l}1.083 \\
1.965\end{array}$ & -1.939 & 0.053 \\
\hline
\end{tabular}

Zmwu: Mann-Whitney U test.

Table 10. The comparison of the scores of the Evaluation Form for the Knowledge Level on Non-pharmacological Methods Used in the Management of Labor Pain with the status of knowledge of non-pharmacological methods used in the management of labor pain and application of the known methods to a pregnant woman $(n=60)$.

\begin{tabular}{|c|c|c|c|c|c|c|}
\hline Sub-scale & $\begin{array}{c}\text { Having } \\
\text { knowledge }\end{array}$ & $\mathbf{n}$ & $\bar{x}$ & \pm SS & $Z_{m w u}$ & p \\
\hline Attitude sub-scale & $\begin{array}{l}\text { Yes } \\
\text { No }\end{array}$ & $\begin{array}{l}42 \\
18\end{array}$ & $\begin{array}{l}12.81 \\
14.61\end{array}$ & $\begin{array}{l}1.612 \\
2.279\end{array}$ & -3.320 & 0.001 \\
\hline Behavior sub-scale & $\begin{array}{l}\text { Yes } \\
\text { No }\end{array}$ & $\begin{array}{l}42 \\
18\end{array}$ & $\begin{array}{l}13.17 \\
12,39\end{array}$ & $\begin{array}{l}1.248 \\
1,944\end{array}$ & -1.802 & 0.072 \\
\hline Sub-scale & $\begin{array}{l}\text { Application of } \\
\text { known method } \\
\text { to a pregnant } \\
\text { woman }\end{array}$ & $\mathbf{n}$ & $\bar{x}$ & \pm SS & $Z_{m w u}$ & $\mathbf{p}$ \\
\hline Attitude sub-scale & $\begin{array}{l}\text { Yes } \\
\text { No }\end{array}$ & $\begin{array}{l}26 \\
33\end{array}$ & $\begin{array}{l}12.27 \\
14.21 \\
\end{array}$ & $\begin{array}{l}1.251 \\
2.103 \\
\end{array}$ & -3.908 & 0.000 \\
\hline Behavior sub-scale & $\begin{array}{l}\text { Yes } \\
\text { No }\end{array}$ & $\begin{array}{l}26 \\
33\end{array}$ & $\begin{array}{l}13.35 \\
12.58\end{array}$ & $\begin{array}{l}0.797 \\
1.855\end{array}$ & -1.633 & 0.103 \\
\hline
\end{tabular}

Zmwu: Mann-Whitney U testi. 


\section{Discussion}

In the research, it was found that $63.3 \%$ of the midwifery students have knowledge of the management of labor pain and $56.7 \%$ of them learnt it in their current school. Of these students, $43.3 \%$ stated that they have knowledge of non-pharmacological methods and applied at least one of these methods to at least one pregnant woman. The most common methods used by the students are massage, listening to music, distraction and imagination, respectively. In the study conducted by Aydın, Turan and Malkoç, ${ }^{[16]}$ it was found that $86.1 \%$ of the students have knowledge of the non-pharmacological methods and learnt these methods during their university education, and the methods they know are respiratory techniques, superficial heat and cold application, and reflexology.

In a study conducted with a different sample group, it was reported that midwifery students had education on the nature of pain and pain-relief methods, $92.6 \%$ of them believed that pharmacological and non-pharmacological methods should be used together to relieve pain, and that the most common methods were distraction, massage, listening to music and imagination. ${ }^{[17]}$ When we compared the midwifery students who participated in our research and the nursing students participated in the study of Özveren and Uçar ${ }^{[17]}$ in terms of non-pharmacological method applications, we found that $6.5 \%$ of the nursing students apply non-pharmacological methods while this rate is $43.3 \%$ for the midwifery students, and this result show that midwifery students are more active in dealing with labor pain and reducing labor pain because of the profession's nature.

The professional support given throughout the labor improves the capability of women to cope with pain and to keep it under control, and it prevents pregnant women to have negative experience. The non-pharmacological methods applied during labor aim to provide active support to the women having labor, meet their emotional needs and requests, make them feel comfortable, improve labor outcomes, boost self-esteem, ensure them to have positive labor experience and facilitate the transition to the motherhood role. In this way, non-pharmacological methods applied upon the consent of pregnant woman help her to relax, participate in the labor and complete the process positively. ${ }^{[18]}$ In our research, all of the midwifery students expressed that the application of non-pharmacological methods increases the confidence of pregnant woman towards healthcare professional,
$98.6 \%$ of them stated that "the appropriate non-pharmacological methods according to the phases of the labor should be applied upon the consent of pregnant woman", $96.7 \%$ of them said that "non-pharmacological methods used for labor pain help pregnant woman to relax", 95\% of them stated expressed that "the respiratory techniques are applied through 4 levels of respiration", 93.3\% of them stated that "providing training to pregnant women for non-pharmacological methods helps their participation in labor positively" and said that "biofeedback, movement/position change, hypnosis, acupuncture, acupressure, music, sophrology, haptonomy and making noise are among the relaxation methods".

According to the research results, the knowledge level of the students regarding the concept of pain is good in general; however, the non-pharmacological methods used for labor pain, its evaluation and control did not provide expected change in students. Aksoy et al. ${ }^{[10]}$ reported that the theoretical knowledge of $51.1 \%$ of the students on labor pain and its management and practice skills of $56.9 \%$ of the students were partially sufficient, and for more active participation in labor, the expectations of the students from the department were active academician support (25.9\%) and the increased number of internship in delivery room (28.2\%) while their expectation from clinics was active professional communication $(44.8 \%)$. These results indicate that the course subjects regarding pain management are limited in the curriculum and the clinical field is insufficient in terms of practicing.

In our research, we found that the trainings, laboratory practices and clinical experiences during school term expand the awareness of the students. Similarly, the attitude sub-scale scores of the 2nd grade midwifery students were higher than other classes, which is statistically significant. This result is inconsistent with the literature. The expected result is that the knowledge levels of $3 \mathrm{rd}$ and 4th grades midwifery students should be higher than the 2nd grade midwifery students in terms of labor, labor pain physiopathology, pain control and non-pharmacological methods. This difference of the students who are in 2nd grade and the age group of 18-19 results from the midwives who graduated from vocational high schools of health and work actively. Midwifery education ensures the integration of theoretical training and clinical application, and helps students to learn by practicing and living in a real setting. The aim of the education is to develop the psychomotor skills of students and establish per- 
manent behavior changes by integrating their theoretical knowledge into their technical skills. As their ages and grades progress and their theoretical knowledge gets enriched, their awareness levels also raise. The clinical fields enable students to observe role models, to perform applications by themselves, and to think about those seen, heard, felt and done. The curriculum provided during education is created by considering the cognitive, behavioral and psychomotor skills, and the targets expected from students in all grades are developed accordingly. ${ }^{[19]}$

We found that the Attitude sub-scale scores of the midwifery students who did not acquire the knowledge on the management of labor pain $(14.36 \pm 2.441)$ were higher than the scores of the students who acquired the knowledge on the management of labor $(12.76 \pm 1.422)$, and this difference was statistically significant. However, we found out that $63.3 \%(n=38)$ of the students in our study had education on the management of labor pain in their current school. This result indicates that the education on the methods used for the management of labor pain did not lead to any change in the attitudes and behaviors. It is necessary to increase the efficiency of education and the number of applied trainings as well as theoretical knowledge in order to create permanent attitude and behavior changes.

One of the limitations of the research is that the study was carried out with 60 students attending midwifery department of a foundation university in İstanbul. The findings can be generalized to the midwifery students reached in 2017-2018 academic year. Acquiring the knowledge level of the sample for the non-pharmacological methods used in the management of labor pain by the self-report of the students, the research design being in the descriptive type, and being unable to observe the relevant methods applied by the students in the clinical field are the other limitations of the study.

\section{Conclusion}

It is needed to increase the knowledge level of the midwifery students on the non-pharmacological methods used in the management of labor pain. In order to do this, the knowledge level of the students should be reinforced by using visual learning techniques and simulation practice methods in addition to their theoretical education. For that purpose, we suggest to include the methods that may be used for the labor pain in the curriculum programs, organizing planned trainings and expanding the learning process throughout the entire education period, creating application fields that the students may practice what they learnt, and to ensure integration between school and hospital to that end. In order to be able to apply non-pharmacological methods, the midwifery students should know the nature, anatomy and physiology of women and normal labor process, and they should be able to transfer this knowledge into their attitudes and behaviors. Therefore, revisions should be made with frequent intervals and the topics that students feel themselves insufficient should be completed by simulations. The models that will increase the activity of students for the non-pharmacological methods in clinical application should be developed, implemented, and the results should be evaluated. Regular evaluation meetings should be held in order to enable the students to discuss their challenges they face in the clinical setting about the labor physiology, labor pain and its management during the labor follow-ups in delivery rooms. In all applications, maternal and fetal health should be taken into consideration, and the students should be taught how they can use the non-pharmacological methods for the management of labor pain according to the phases of the labor. Beginning from the 2 nd grade vocational classes, non-pharmacological methods should be explained in all applied classes and the subject should be reinforced by simulations. When teaching psychomotor skills to midwifery students in vocational training laboratories, the practices that will help students to solve problems, make decisions and gain skills to associate their knowledge with the clinical setting should be conducted. The importance of involving the families of pregnant women into all applications should be highlighted during the education.

Conflicts of Interest: No conflicts declared.

\section{References}

1. Taşkın L. Doğum ve kadın sağlığı hemşireliği. 8. basım. Ankara: Sistem Ofset Matbaacılık; 2004. p. 312-23.

2. Şirin A, Kavlak O. Kadın sağlı̆̆ı. İstanbul: Bedray Basım Yayıncılık; 2008. p. 664-8.

3. Kömürcü N, Ergin A. Doğum ağrısında farmakolojik olmayan yöntemlerin kullanımı. Hemşirelikte Eğitim ve Araştırma Dergisi 2009;6:29-35.

4. Berkiten A. Doğumun I. ve II. evresinde gebeye uygulatılan pozisyonların doğum sürecine etkisi. Doktora Tezi, Marmara Üniversitesi Sağlık Bilimleri Enstitüsü, İstanbul, 2005.

5. Taşçı E, Sevil Ü. Doğum ağrısına yönelik farmakolojik olmayan yaklaşımlar. Genel Tıp Dergisi 2007;17:181-6. 
6. Coşkun A. Kadın sağlığı ve hastalıkları hemşireliği el kitabı. İstanbul: Koç Üniversitesi Yayınları; 2012. p. 195-206

7. Erdine S. Ağrı mekanizmaları ve ağrıya genel yaklaşım. In: Erdine S, editör. Ağrı. 3. baskı. İstanbul: Nobel Tıp Kitabevleri; 2007. p. 37-49.

8. Kannan S, Jamison RN, Dattla S. Maternal satisfaction and pain control in women electing natural child birth. Reg Anesth Pain Med 2001;26:468-72.

9. Mete S, Uludağ E. Doğum eyleminde destekleyici bakım. Cumhuriyet Hemşirelik Dergisi 2014;3:22-9.

10. Aksoy Ö, Pınar Ş, Yurtsal Z, Uçuk S, Şahin T, Yilan H. Dogum eylemine aktif olarak katılan ebelik ögrencilerinin kayg1 ve öz-güven düzeylerinin incelenmesi. Gümüşhane Üniversitesi Sağlık Bilimleri Dergisi 2017;6:2.

11. Eti Aslan F, Karadakovan A. Dahili ve cerrahi hastalarda bakım. Adana: Nobel Kitabevi, Adana, 2011.

12. İpek A, Eryılmaz G. Doğum eyleminde alt sirt bölgesine uygulanan derisel terapi yöntemlerinin doğum ağrısı algısına ve doğumun süresine etkisi. Yüksek lisans tezi, Atatürk Üniversitesi Sağlık Bilimleri Enstitüsü, Erzurum, 2014.

13. Phumdoung S, Good M. Music reduces sensation and distress of labor pain. Pain Manag Nurs 2003;4:54-61.
14. Anderson FWJ, Johnson CT. Complementary and alternative medicine in obstetrics. Int J Gynaecol Obstet 2005;91:116-24.

15. Avcıbay B, Alan S. Doğum ağrısında kullanılan nonfarmakolojik yöntemler. Mersin Üniversitesi Sağlık Bilimleri Dergisi 2011; $4: 18-24$.

16. Aydın Y, Turan Z, Malkoç ÖÖ. Ebelik intörn öğrencilerinin doğum ağrısının kontrolünde uygulanan non-farmakolojik yöntemler hakkında bilgi düzeylerinin belirlenmesi. Ebelikte Güncel Yaklaşımlar Sempozyumu, Sakarya Üniversitesi, 30 Nisan 2015.

17. Özveren H, Uçar H. Öğrenci hemşirelerin ağrı kontrolünde kullanılan farmakolojik olmayan bazı yöntemlere ilişkin bilgileri. Hacettepe Üniversitesi Sağlık Bilimleri Fakültesi Hemşirelik Dergisi 2009;16:59-72.

18. Karaçam Z, Akyüz EÖ. Doğum eyleminde destekleyici bakım ve ebe/hemşirenin rolü. İstanbul Üniversitesi Florence Nightingale Hemşirelik Dergisi 2011;19:45-53.

19. Titrek O, Hakkakul MA, Varlı S. Hemşirelik bölümü staj uygulamalarının etkililik düzeyine ilişkin öğrenci ve rehber hemşirelerin görüşleri. Abant İzzet Baysal Üniversitesi Ĕ̆itim Fakültesi Dergisi 2015;15:264-80.

Bu makalenin kullanım izni Creative Commons Attribution-NoCommercial-NoDerivs 3.0 Unported (CC BY-NC-ND3.0) lisansı aracılığılla bedelsiz sunulmaktadır. / This work is licensed under the Creative Commons Attribution-NonCommercial-NoDerivs 3.0 Unported (CC BY-NC-ND3.0) License. To view a copy of this license, visit http://creativecommons.org/licenses/by-nc-nd/3.0/ or send a letter to Creative Commons, PO Box 1866 , Mountain View, CA 94042, USA. 